[Report]

\title{
Comparison of Chemicals in Mainstream Smoke in Heat-not-burn Tobacco and Combustion Cigarettes
}

\author{
Kanae BeKki*, Yohei Inaba, Shigehisa Uchiyama and Naoki Kunugita \\ Department of Environmental Health, National Institute of Public Health. Minami, Wako-shi, Saitama 351-0197, Japan
}

\begin{abstract}
Because of the health effects of secondhand smoke, the Japanese government is trying to establish an effective law for total avoidance of secondhand smoke in indoor environments for tobacco-free Tokyo Olympic and Paralympic games 2020, as requested by the International Olympic Committee (IOC) and the World Health Organization (WHO). Meanwhile, Philip Morris International has begun selling a new heat-not-burn tobacco, iQOS, which it claims is designed not to produce secondhand smoke. There is little scientific data, however, of the hazards and toxicity of iQOS. In this study, we evaluated several harmful compounds (nicotine, tar, carbon monoxide (CO) and tobacco-specific nitrosamines (TSNAs)) in the mainstream smoke and fillers of iQOS, and compared their concentrations with those from conventional combustion cigarettes. The concentrations of nicotine in tobacco fillers and the mainstream smoke of iQOS were almost the same as those of conventional combustion cigarettes, while the concentration of TSNAs was one fifth and CO was one hundredth of those of conventional combustion cigarettes. These toxic compounds are not completely removed from the mainstream smoke of iQOS, making it necessary to consider the health effects and regulation of iQOS.
\end{abstract}

Keywords : heat-not-burn tobacco, tar, nicotine, carbon monoxide, tobacco specific nitrosamines.

(Received May 12, 2017, accepted July 31, 2017)

\section{Introduction}

The health effects of secondhand smoke have been widely recognized as a common issue worldwide by the World Health Organization (WHO) Framework Convention on Tobacco Control (FCTC) [1], and secondhand smoke was categorized as a carcinogen to humans (Group 1) by the International Agency for Research on Cancer (IARC) [2]. On the other hand, tobacco companies are developing new products, such as electronic cigarette and heat-not-burn tobacco. iQOS, a representative product of heat-not-burn tobacco sold by Philip Morris International Inc. (NY, USA), is spreading rapidly in Japan. Philip Morris claims that the revolu- tionary features of iQOS are no emission of secondhand smoke, tobacco specific smell or cigarette ash. Considering these features, it can be assumed that the number of iQOS users will increase in the future.

The Japanese government is considering measures to prevent secondhand smoke, based on FCTC article 8 , because the International Olympic Committee (IOC) and the WHO agreed to promote tobacco-free Tokyo Olympic and Paralympic Games 2020. The government is trying to establish an amendment to prevent secondhand smoke and to totally prohibit smoking in indoor environments, especially in restaurants, bars, etc, because at present there are no legal restraints in indoor or outdoor environments in Japan. In spite of

*Corresponding Author: Kanae BeKki, Department of Environmental Health, National Institute of Public Health, 2-3-6 Minami, Wako-shi, Saitama 351-0197, Japan, Tel: 048-458-6258, Fax: 048-458-6270, E-mail: bekki.k.aa@niph.go.jp 
increasing numbers of heat-not-burn tobacco users, however, there has been no explicit risk assessment of iQOS, because there is only limited scientific evidence of its safety.

In this first study of the evaluation of heat-not-burn tobacco, we analyzed the concentration levels of basic harmful components (nicotine, tar, carbon monoxide (CO) and tobacco-specific nitrosamines (TSNAs)) in the mainstream smoke and tobacco fillers of first-generation iQOS, which became available in Japan in 2014.

\section{Materials and Methods}

\section{Apparatus and reagents}

Gas chromatography (GC) coupled with a flame ionization detector (FID) was used to quantify the nicotine in the mainstream smoke and tobacco filler. The analytical column was HP-INNOWAX $(30 \mathrm{~m} \times 0.25 \mathrm{~mm}$ i.d, $0.25 \mu \mathrm{m})$ (Agilent technologies, CA, USA). Liquid chromatography-tandem mass spectrometry (LCMS/MS), Micromass Quattro LC (Waters, MA, USA) was used to quantify TSNAs. The analytical column used for LC-MS/MS was Zorbax Eclipse XDB C-18 $(2.1 \times 150 \mathrm{~mm}, 3.5 \mu \mathrm{m})$ (Agilent technologies). A nondispersive infrared analyzer (NDIR, IR200) (Yokogawa Electronic Co., Tokyo, Japan) was used for the measurement of CO. Nicotine $97 \%$, sodium hydrate $>97 \%$, L-ascorbic acid $>99.6 \%$, dibasic potassium phosphate $>99.0 \%$, citric acid $>98 \%, n$-hexane $>96 \%$, dichloromethane $>99 \%$, dimethylsulfoxide $>99.0 \%$, 2-propanol $>99.7 \%$, methanol (High performance liquid chromatography (HPLC) grade) $>99.9 \%$, acetic acid $>99.7 \%$ and hydrogen peroxide $30 \%$ were purchased from Wako Pure Chemical Industries, Ltd. (Osaka, Japan). Acetonitrile and ammonium acetate $\geq 99.99 \%$ were purchased from Sigma-Aldrich Inc. (St. Louis, MO, USA), and $n$-heptadecane was purchased from Tokyo kasei Co., Ltd. (Tokyo, Japan). N'-nitrosonornicotine (NNN), 4-(Methylnitrosamino)-1-(3-pyridyl)1-butanone (NNK), $N$ '-nitrosoanatabine (NAT), $N$ '-nitrosoanabasine (NAB), NNN- $d_{4}, \mathrm{NNK}-d_{3}, \mathrm{NAT}-d_{4}$ and $\mathrm{NAB}-d_{4}$ were obtained from Tronto research chemicals. Concentrated nitric acid $60 \%$ was purchased from Kanto Chemical Co., Inc. (Tokyo, Japan). The water used for the sample preparation and analysis was deionized, and further purified using a Milli-Q water system (Millipore
Co., Bedford, MA, USA). In this study, we used conventional combustion cigarettes ( $3 \mathrm{R} 4 \mathrm{~F}$ and $1 \mathrm{R} 5 \mathrm{~F}$ ) from the University of Kentucky (Lexington, KY, USA), and iQOS (regular and menthol) from Philip Morris International Inc. (NY, USA). According to a previous report of conventional combustion cigarettes, $1 \mathrm{R} 5 \mathrm{~F}$ is a low yield cigarette, and $3 \mathrm{R} 4 \mathrm{~F}$ is a relatively high yield cigarette [3]. According to International Organization for Standardization (ISO) 3402, these cigarettes were used for measurement after being placed at $22^{\circ} \mathrm{C}$ temperature and $60 \%$ humidity for 2 days [4].

\section{Preparation of mainstream smoke and filler samples}

Mainstream smoke was collected according to the intense regime described in Standard operating procedure (SOP) 01 [5] and health Canada, official method T-115 [6]. Briefly, mainstream smoke was collected under the conditions of $55 \mathrm{~m} l$ puff volume, $2 \mathrm{~s}$ puff duration, $30 \mathrm{~s}$ puff interval, and $100 \%$ blocking of the filter ventilation holes with Mylar adhesive tape, although there are no filter ventilation holes in iQOS. The puff number of one conventional combustion cigarette was 9 times, and that of Heat-not-burn tobacco was 11 times. Each sampling was performed by 3 conventional combustion cigarettes or Heat-notburn tobacco. The tobacco fillers were taken out from each cigarette for analysis of each component, and we prepared samples fractured by a blender (KC-4508) (Twinbird Co., Niigata, Japan). These samples were extracted by 2-propanol and ammonium acetate, and analyzed by an appropriate method of SOP for nicotine and TSNAs, as described below.

\section{Measurement of concentrations of nicotine, tar, CO and TSNAS}

As a member of WHO collaborating centers for tobacco control, we developed the WHO tobacco laboratory network (TobLabNet) Official Method SOP for the measurement of each component of tobacco filler and combustion cigarette. In this study, we applied these methods for evaluating iQOS. We measured the nicotine, $\mathrm{CO}$ and TSNAs in the mainstream smoke of iQOS according to the WHO TobLabNet Official Method SOP03 [7] and SOP10 [8]. Nicotine and CO were measured using GC-FID and NDIR after the collection and pretreatment of mainstream smoke. TS- 
NAs were measured using LC-MS/MS. The nicotine in the tobacco fillers was measured according to the method of SOP04 [9], and the TSNAs in the tobacco fillers were measured according to the method of SOP03. We used the same analytical instruments for the tobacco fillers and the mainstream smoke. The amount of tar exhausted in the mainstream smoke was calculated by subtracting the amount of nicotine and water from the total particulate matter (TPM).

\section{Results and Discussion}

The concentrations of tar, nicotine, TSNAs and CO detected in the tobacco filler and mainstream smoke of iQOS are shown in Tables 1 and 2, respectively. The transfer rates of each compound from tobacco filler to mainstream cigarette smoke are shown in Table 2. These concentrations were compared with conventional combustion cigarettes $1 \mathrm{R} 5 \mathrm{~F}$ and $3 \mathrm{R} 4 \mathrm{~F}$, which are widely used for tobacco research.

\section{Concentrations of tar, nicotine and $\mathrm{CO}$ in mainstream smoke and filler of iQOS}

Tar and nicotine are the major components in the particulate phase, and $\mathrm{CO}$ is a chemical compound in the gas phase of mainstream smoke. The amounts of tar and nicotine are printed on the tobacco packages, but the contents of nicotine and tar in iQOS remain to be defined, in contrast to other combustion cigarettes in Japan. Therefore, we measured the concentrations of these compounds in the samples of iQOS. The concentrations of nicotine in the fillers of iQOS were 15.7 $\mathrm{mg} / \mathrm{g}$ (regular) and $17.1 \mathrm{mg} / \mathrm{g}$ (menthol) (Table 1), almost the same as in conventional combustion cigarettes (3R4F: $19.7 \mathrm{mg} / \mathrm{g}, 1 \mathrm{R} 5 \mathrm{~F}: 15.9 \mathrm{mg} / \mathrm{g}$ ) (Table 1). Nicotine in the mainstream smoke of iQOS (regular: $1.1 \mathrm{mg} / \mathrm{cig}$, menthol: $1.2 \mathrm{mg} / \mathrm{cig}$ ) (Table 2) was also detected at a level comparable with 1R5F (1.0 mg/cig) and relatively lower than 3R4F (1.7 mg/cig) (Table 2). By using these values, we estimated the transfer rates of nicotine at $23.4 \%$ (regular) and $23.5 \%$ (menthol) (Table 2), indicating that iQOS has more effective transfer rates than the conventional combustion cigarettes (3R4F: 11.3\%, 1R5F: 11.5\%) (Table 2). On the other hand, the concentration of tar in the mainstream smoke of iQOS was half or less than that of the con- ventional combustion cigarettes. From a comparison with other data reported by Schaller et al., these concentrations were at almost the same level [10].

Next we measured the concentration of $\mathrm{CO}$ in the mainstream smoke of iQOS. It is well known that $\mathrm{CO}$ causes adverse effects on the lungs, hearts and blood vessels [11], and there are many reports on the mechanism of $\mathrm{CO}$ generation processes in cigarette smoke $[12,13]$. In these reports, $\mathrm{CO}$ is produced by an oxidative reaction with the carbon constituent, especially at a higher range of combustion temperature $>350^{\circ} \mathrm{C}$. Because combustion cigarettes operate by heating at $900^{\circ} \mathrm{C}$ during a puff, while iQOS can operate at a maximum of $350^{\circ} \mathrm{C}$, we anticipated a lower level of $\mathrm{CO}$ exhaust from iQOS than from combustion cigarettes. We found that the actual concentration of $\mathrm{CO}$ emitted by iQOS (regular: $0.44 \mathrm{mg} / \mathrm{cig}$, menthol: $0.43 \mathrm{mg} / \mathrm{cig}$ ) (Table 2) was approximately one-hundredth of that emitted by the conventional combustion cigarettes (3R4F: $33.0 \mathrm{mg} / \mathrm{cig}$, 1R5F:29.7 mg/cig) (Table 2). The lower concentrations of $\mathrm{CO}$ in the mainstream smoke of iQOS was considered to be due to its heating mechanism.

\section{Concentrations of TSNAs in mainstream smoke and filler of $i Q O S$}

TSNAs are well known carcinogenic compounds in cigarettes, and are mainly generated from nicotine in the manufacturing process of tobacco leaf. In this experiment, we analyzed the concentration levels of four major TSNAs (NNN, NAT, NAB, NNK) in tobacco filler and in the mainstream smoke of iQOS and conventional combustion cigarettes. Previous in vivo studies have shown that NNK and NNN, especially, are highly carcinogenic [14], and are evaluated as carcinogenic to humans (Group 1) by the IARC, while NAB and NAT are not so highly carcinogenic.

When we measured the four kinds of TSNAs in the fillers of iQOS and conventional combustion cigarettes, they were detected at almost the same ratio in every kind of cigarette. The concentration levels of TSNAs detected in tobacco fillers and mainstream smoke of iQOS, however, were significantly lower than those of conventional combustion cigarettes, although the transfer rates of NNN, NAT and NNK in iQOS were slightly higher than those in conventional combustion cigarettes. According to a previous report about the 
levels of TSNAs in commercial cigarettes [15], it was suggested that the downward trend of TSNA levels in mainstream smoke reflects the improvements in quality achieved by industry and the agricultural community for the reduction of TSNA levels. We speculated that the lower TSNA levels in iQOS found in this study was achieved by a specific technique in the production of tobacco leaf.

\section{Conclusion}

In this study, we could provide important information showing that the concentration levels of hazardous compounds in the mainstream smoke of iQOS are much lower than those in conventional combustion cigarettes. Although it is low concentration, toxic compounds are definitely included in the mainstream

Table 1. Concentrations of tar, nicotine, CO and TSNAs in tobacco fillers of iQOS (regular and menthol) and conventional combustion cigarettes (3R4F and $1 \mathrm{R5F})$

\begin{tabular}{|c|c|c|c|c|c|c|c|c|}
\hline \multirow[t]{2}{*}{ Element } & \multicolumn{4}{|c|}{ Tobacco filler (concentration per gram) } & \multicolumn{4}{|c|}{ Tobacco filler (concentration per cigarette) } \\
\hline & $\begin{array}{l}\text { iQOS } \\
\text { regular }\end{array}$ & $\begin{array}{l}\text { iQOS } \\
\text { menthol }\end{array}$ & $3 \mathrm{R} 4 \mathrm{~F}$ & $1 \mathrm{R} 5 \mathrm{~F}$ & $\begin{array}{l}\text { iQOS } \\
\text { regular }\end{array}$ & $\begin{array}{l}\text { iQOS } \\
\text { menthol }\end{array}$ & $3 \mathrm{R} 4 \mathrm{~F}$ & $1 \mathrm{R} 5 \mathrm{~F}$ \\
\hline Tar & - & - & - & - & $\begin{array}{c}- \\
(\mathrm{mg} / \mathrm{cig})\end{array}$ & - & - & - \\
\hline Nicotine (mg/g) & $15.7 \pm 0.2$ & $17.1 \pm 0.6$ & $19.7 \pm 0.2$ & $15.9 \pm$ & $4.7 \pm 0.1$ & $5.1 \pm 0.2$ & $15.0 \pm 0.1$ & $8.7 \pm 0.1$ \\
\hline TSNAs (ng/g) & & & & & (ng/cig) & & & \\
\hline $\mathrm{NNN}$ & $314.7 \pm 4.8$ & $336.7 \pm 9.3$ & $2477.0 \pm 86.0$ & $3067.0 \pm 122.0$ & $94.4 \pm 1.4$ & $101.0 \pm 2.8$ & $1889.0 \pm 66.0$ & $1691.0 \pm 67.0$ \\
\hline NAT & $332.5 \pm 5.2$ & $315.0 \pm 6.8$ & $1758.0 \pm 56.0$ & $1656.0 \pm 55.0$ & $99.8 \pm 1.6$ & $94.5 \pm 2.0$ & $1341.0 \pm 43.0$ & $913.0 \pm 30.0$ \\
\hline NAB & $18.5 \pm 2.5$ & $17.2 \pm 1.2$ & $85.0 \pm 1.0$ & $84.0 \pm \quad 2.0$ & $5.6 \pm 0.8$ & $2.6 \pm 0.4$ & $65.0 \pm 1.0$ & $46.0 \pm 1.0$ \\
\hline NNK & $170.4 \pm 1.0$ & $194.1 \pm 2.0$ & $697.0 \pm 31.0$ & $747.0 \pm 19.0$ & $51.1 \pm 0.3$ & $58.2 \pm 0.6$ & $532.0 \pm 24.0$ & $412.0 \pm 10.0$ \\
\hline Total of TSNA & $836.1 \pm 9.1$ & $863.0 \pm 13.4$ & $5018.0 \pm 83.0$ & $5554.0 \pm 167.0$ & $250.8 \pm 2.7$ & $258.9 \pm 4.0$ & $3826.0 \pm 63.1$ & $3061.0 \pm 92.0$ \\
\hline $\mathrm{CO}$ & - & - & - & - & - & - & - & - \\
\hline
\end{tabular}

Values are mean $\pm \mathrm{SD}$, TSNAs: tobacco specific nitrosamines, NNN: $N$-nitrosonornicotine, NAT: $N$ '-nitrosoanatabine, NAB: $N$-nitrosoanabasine, NNK: Nicotine-derived nitrosamine ketone, $\mathrm{CO}$ : carbon monoxide

Table 2. Concentrations of tar, nicotine, $\mathrm{CO}$ and TSNAs in mainstream cigarette smoke and transfer rates of each component in iQOS (regular and menthol) and conventional combustion cigarettes (3R4F and 1R5F)

\begin{tabular}{|c|c|c|c|c|c|c|c|c|}
\hline \multirow[t]{2}{*}{ Element } & \multicolumn{4}{|c|}{ Mainstream cigarette smoke } & \multicolumn{4}{|c|}{ Transfer rate $(\%)$} \\
\hline & iQOS regular & iQOS menthol & $3 \mathrm{R} 4 \mathrm{~F}$ & $1 \mathrm{R} 5 \mathrm{~F}$ & $\begin{array}{l}\text { iQOS } \\
\text { regular }\end{array}$ & $\begin{array}{l}\text { iQOS } \\
\text { menthol }\end{array}$ & 3R4F & $1 \mathrm{R} 5 \mathrm{~F}$ \\
\hline TPM (mg/cig) & $44.0 \pm 11.4$ & $49.9 \pm 8.6$ & $36.9 \pm 1.9$ & $28.9 \pm 2.3$ & - & - & - & - \\
\hline Water (mg/cig) & $33.1 \pm 10.2$ & $35.3 \pm 8.3$ & $10.1 \pm 0.9$ & $8.8 \pm 1.1$ & - & - & - & - \\
\hline Tar (mg/cig) & $9.8 \pm 3.0$ & $13.4 \pm 2.2$ & $25.2 \pm 1.5$ & $19.2 \pm 1.3$ & - & - & - & - \\
\hline Nicotine (mg/cig) & $1.1 \pm 0.1$ & $1.2 \pm 0.1$ & $1.7 \pm 0.1$ & $1.0 \pm 0.1$ & 23.4 & 23.5 & 11.3 & 11.5 \\
\hline $\mathrm{CO}$ (mg/cig) & $0.44 \pm 0.04$ & $0.43 \pm 0.04$ & $33.0 \pm 1.8$ & $29.7 \pm 1.7$ & - & - & - & - \\
\hline \multicolumn{9}{|l|}{ TSNAs (ng/cig) } \\
\hline NNN & $19.2 \pm 2.1$ & $24.9 \pm 3.5$ & $311.1 \pm 24.3$ & $240.7 \pm 6.6$ & 20.3 & 24.7 & 16.4 & 14.2 \\
\hline NAT & $34.0 \pm 3.1$ & $37.2 \pm 3.9$ & $246.4 \pm 16.9$ & $183.1 \pm 6.0$ & 34.1 & 39.4 & 18.3 & 20.1 \\
\hline NAB & $4.5 \pm 0.5$ & $5.5 \pm 0.6$ & $30.4 \pm 2.0$ & $26.2 \pm 0.5$ & 80.3 & 211.5 & 46.8 & 57.0 \\
\hline NNK & $12.3 \pm 1.5$ & $13.8 \pm 2.6$ & $250.4 \pm 13.7$ & $107.0 \pm 5.0$ & 24.1 & 23.7 & 47.1 & 26.0 \\
\hline Total of TSNA & $70.0 \pm 7.2$ & $81.4 \pm 10.4$ & $838.2 \pm 53.7$ & $557.1 \pm 15.7$ & 27.9 & 31.4 & 21.9 & 18.2 \\
\hline
\end{tabular}

Values are mean $\pm \mathrm{SD}$, TPM: total particulate matter, TSNAs: tobacco specific nitrosamines, NNN: $N$-nitrosonornicotine, NAT: $N$ '-nitrosoanatabine, NAB: $N$-nitrosoanabasine, NNK: nicotine-derived nitrosamine ketone, $\mathrm{CO}$ : carbon monoxide 
smoke of iQOS. Mitova et al. showed that exhalation from smokers increased the background levels of some compounds, such as acetaldehyde and nicotine, in the office [16], so adverse effects of these compounds may easily spread to an unspecified population in the public and in crowded indoor places, such as restaurants via secondhand smoking. Various other hazardous compounds, such as volatile organic compounds (VOCs), are also included in both the particle and gas phases of mainstream smoke of iQOS $[10,17]$. In consideration of this, we need further chemical evaluation and studies of their health effects in order to support regulation of iQOS in the future.

\section{Acknowledgements}

This research was partially supported by the Health and Labour Science Research Grants from Ministry of Health, Labour and Welfare of the Japanese Government, and the practical research project for life-style related diseases including cardiovascular diseases and diabetes mellitus from Japan Agency for Medical Research and Development, AMED.

\section{Conflicts of Interest}

The authors declare no conflicts of interest.

\section{References}

1. Hori M, Tanaka H, Wakai K, Sasazuki S \& Katanoda K (2016): Secondhand smoke exposure and risk of lung cancer in Japan: a systematic review and meta-analysis of epidemiologic studies. Jpn J Clin Oncol 46: 942-951

2. International Agency for Research on Cancer (2007): Some tobacco-specific $n$-nitrosamines. In: Smokeless tobacco and some tobacco-specific $n$-nitrosamines. IARC monographs on the evaluation of carcinogenic risks to humans 89 . IARC, Lyon pp 421-583

3. Cooperation Centre for Scientific Research Relative to Tobacco (CORESTA) (2013): Reference products used in tobacco and smoke analyses. Tob J Int 2013(2): 150-154

4. International Organization for Standardization (ISO) (1999): Tobacco and tobacco products-atmosphere for conditioning and testing. ISO 3402, Geneva pp 1-3

5. World Health Organization (WHO) (2012): Standard operating procedure for intense smoking of cigarettes. WHO Tobacco Laboratory Network (TobLabNet) Official Method SOP 01. WHO, Geneva pp 1-7

6. Health Canada (1999): Official method T-115, determination of "Tar", nicotine and carbon monoxide in mainstream tobacco smoke. Health Canada, Ottawa pp 1-6

7. World Health Organization (WHO) (2014): Standard operating procedure for determination of tobacco-specific nitrosamines in mainstream cigarette smoke under ISO and intense smoking conditions. WHO Tobacco Laboratory Network (TobLabNet) Official Method SOP 03. WHO, Geneva pp 1-22

8. World Health Organization (WHO) (2016): Standard operating procedure for determination of nicotine and carbon monoxide in mainstream cigarette smoke under intense smoking conditions. WHO Tobacco Laboratory Network (TobLabNet) Official Method SOP10. WHO, Geneva pp 1-21

9. World Health Organization (WHO) (2014): Standard operating procedure for determination of nicotine in cigarette tobacco filler. WHO Tobacco Laboratory Network (TobLabNet) Official Method SOP04. WHO, Geneva pp 1-15

10. Schaller JP, Pijnenburg JP, Ajithkumar A \& Tricker AR (2016): Evaluation of the tobacco heating system 2.2. part 3: Influence of the tobacco blend on the formation of harmful and potentially harmful constituents of the tobacco heating system 2.2 aerosol. Regul Toxicol Pharmacol 81: S48-S58

11. U.S. Department of Health and Human Services, Centers for Disease Control, Office on Smoking and Health (2014): The health consequences of smoking: 50 years of progress. A report of the Surgeon General. U.S. Department of Health and Human Services, Rockville pp 1-943

12. Baker RR (2006): Smoke generation inside a burning cigarette: modifying combustion to develop cigarettes that may be less hazardous to health. Prog Energy Combust Sci 32: 373-385

13. Djulančić N, Radojičić V \& Srbinovska M (2013): The influence of tobacco blend composition on carbon monoxide formation in mainstream cigarette smoke. Arh Hig Rada Toksikol 64: 107-113

14. Hecht SS (1996): Recent studies on mechanisms of bio- 
activation and detoxification of 4-(methylnitrosamino)1-(3-pyridyl)-1-butanone (NKK), a tobacco-specific lung carcinogen. Crit Rev Toxicol 26: 163-181

15. Appleton S, Olegario RM \& Lipowicz PJ (2013): TSNA levels in machine-generated mainstream cigarette smoke: 35 years of data. Regul Toxicol Pharmacol 66: 197-207

16. Mitova MI, Campelos PB, Goujon-Ginglinger CG, Maeder S, Mottier N, Rouget EG, Tharin M \& Tricker AR (2016): Comparison of the impact of the tobacco heating system 2.2 and a cigarette on indoor air quality. Regul Toxicol Pharmacol 80: 91-101

17. Uchiyama S, Hayashida H, Izu R, Inaba Y, Nakagome $H$ \& Kunugita N (2015): Determination of nicotine, tar, volatile organic compounds and carbonyls in mainstream cigarette smoke using a glass filter and a sorbent cartridge followed by the two-phase/one-pot elution method with carbon disulfide and methanol. J Chromatogr A 1426: 48-55 
加熱式タバコと燃焼式タバコの主流煙中に含まれる有害成分の比較

戸次 加奈江, 稲葉 洋平, 内山 茂久, 欅田 尚樹

国立保健医療科学院 生活環境研究部 衛生環境管理研究領域

要旨：受動喫煙による健康影響が懸念される中,たばこ規制枠組条約 (FCTC) 締約国として我が国でもその対 策が推進され, 現在, 2020年東京オリンピック・パラリンピックの開催に向けて, 受動喫煙防止のための効果的な法 の整備が国際オリンピック委員会 (IOC) と世界保健機関 (WHO)の要請のもと進められている。一方, Philip Morrisは 新型タバコとして, 加熱式タバコ iQOSの販売を開始した。iQOS は, 副流煙が低減化された新型タバコとして販売さ れているものの, 受動契煙や毒性に関しては限られた情報しかない. 本研究では, 科学的な観点から iQOSを評価す るため, タバコ葉抒よびタバコ主流煙中の主成分であるタール, ニコチン, 一酸化炭素および夕バコ特異的ニトロソ アミン (TSNAs)の濃度レベルを従来の燃燒式タバコ(標準タバコ) と比較した．iQOS専用の夕バコ葉拉よび主流煙 からは, 標準タバコと同程度のニコチンが検出されたのに対して, TSNAsは, タバコ葉および主流煙のいずれも標準 タバコの 5 分の 1 程度にまで濃度が低減され, 燃焼マーカーとしても知られる一酸化炭素 $(\mathrm{CO})$ は, 標準夕バコの 100 分の 1 程度の濃度であった。しかしながら,この様な有害成分は完全に除去されているわけではなく,少なからず主 流煙に含まれていた，今後, iQOSの使用規制には, 有害成分の情報に加え, 受動喫煙や毒性などの情報から, 総合的 に判断していく必要がある.

キーワード : 加熱式タバコ, タール, ニコチン, 一酸化炭素, タバコ特異的ニトロソアミン. 